\title{
The Causal Relationship between Exports, Imports and Economic Growth in Palestine
}

\author{
Zahra' Fannoun ${ }^{1}$ and Islam Hassouneh ${ }^{2, *}$ \\ ${ }^{1}$ College of Business Administration, Hebron University, P.O. Box 40, Hebron, Palestine \\ ${ }^{2}$ College of Administrative Science and Informatics, Palestine Polytechnic University (PPU), P.O. Box 198, \\ Abu Ruman, Hebron, Palestine
}

\begin{abstract}
The relationship between exports, imports and economic growth is investigated for the Palestinian economy over the period 2000-2018, using quarterly data. To do so, cointegration test using Johansen's approach as well as vector error correction technique are used. Findings confirm the presence of long-run equilibrium relationship between exports, imports and output growth. Results also support the existence of bidirectional long-run causality between exports, imports and output growth. As for the short-run causality, findings support both the export-led import and the import-led export hypotheses. Further, imports are found to Granger cause economic growth. Policy makers should be aware of the importance of trade to stimulate economic growth.
\end{abstract}

Keywords: Exports, imports, economic growth, cointegration, VECM.

\section{INTRODUCTION}

Economic growth is one of the prime long-run concerns of macroeconomists and policy makers (Chokri, El Ammari, and Bouchrika 2018). For a society to achieve an increasing standard of living, total output must growth. The economic growth is measured through the concept of Gross Domestic Product (GDP). Theoretically, the four components of GDP are personal consumption, business investment, government expenditure and net exports (export minus import). In this study, we focus on this issue by analyzing the impact of both export and import on economic growth.

Export expansion is viewed as a key determinant of economic growth since it's considered as one of the most important sources of foreign exchange earnings that ease the pressure on the balance of payments and create employment opportunities (Abu-Shihab, Soufan, and Abdul-Khaliq 2014). Unlike export, import leads to the exit of the local currency and a deterioration of the trade balance and thereby weakening economic growth (Bakari and Mabrouki 2017). However, in some countries, import can be considered as a source of economic growth. More specifically, according to Helpman and Krugman (1985), import can serve as a channel for long-run economic growth as it provides intermediate goods which in turn increases capital formation and thereby stimulate economic growth. Furthermore, import can encourage output growth by serving as a medium for the transfer of knowledge from developed to developing countries (Lawrence and Weinstein 1999).

*Address correspondence to this author at the Palestine Polytechnic University, Palestine; Tel: +9702235505; Fax: +9702235505; E-mail: islamh@ppu.edu
Empirical studies in the literature argue that the causal direction of the effect of trade (exports and imports) on economic growth is still debated. Generally, results from previous studies varies between in-favour and not in-favour of four main hypotheses: Export-Led Growth (ELG), Growth-Led Export (GLE), Import-Led Growth (ILG) and Growth-Led Import (GLI). More specifically, many empirical studies argue that export growth and openness to foreign countries is an important determinate of economic growth (see, Awokuse 2007; Asafu-Adjaye and Chakraborty 1999). However, empirical support for GLE hypothesis is relatively stronger (Ghartey 1993; Kubo 2011). According to Krugman (1984), export growth could be stimulated by productivity gains caused by increases in domestic levels of skilled-labor and technology. Other empirical studies argue that imports are the economic engine of growth. As mentioned above, imports provide local firms with access to needed foreign intermediate goods and technology that contribute to the increase in economic growth. The fourth hypothesis suggests that economic growth may lead to import expansion (see, Saaed and Hussain 2015; Hye 2012; Hye, Wizarat, and YeapLau 2013).

The objective of this study is to formally assess the causal relationship between exports, imports and economic growth in Palestine. The analysis of the Palestinian economy is important due to its unique situation. More specifically, the Israeli control over the Palestinian territory as well as the political instability has made the Palestinian economy an exceptional economy. According to Palestinian Central Bureau of Statistics (PCBS 2018), in 2017 the real GDP of Palestine, using 2010 as the base year, was around 
$\$ 10.8$ billion, compared with $\$ 10.4$ billion in 2016 and $\$ 10$ billion in 2015. In 2017, Palestine exported $\$ 935$ million and imported $\$ 4.78$ billion, resulting in a negative trade balance of $\$ 3.8$ billion.

The rest of the study is structured as follows: section 2 presents the theoretical framework. A literature review of previous research, on the relationship between trade and economic growth, is presented in Section 3. The four and the fifth sections are devoted to discuss methodology and data used, respectively. The discussion of the results is presented in section 6 and section 7 summarizes the main conclusions.

\section{THEORETICAL FRAMEWORK}

Economic growth is one of the most important indicators of a country's well-being. Economists tend to interpret the fluctuations in economic growth by interpreting the relationship between trade (exports and imports) and economic growth. Exports are considered as one of the most important sources of foreign currency income that ease the pressure on the balance of payments and create employment opportunities and thus income. But exports are just half of the trade equation. Imports also play an important role in enhancing economic growth if properly managed. It provides many jobs in the local country as well as imported goods can be used to re-manufacture them again. Imports can also generate an overall economic growth as it provides local firms access to foreign technology and knowledge. Furthermore, imports have a large positive effect on productivity growth through its effect on local innovation and research and development through import competition (Hashem and Masih 2014).

The allegation that justifies the role of international trade in economic growth is not new. It goes back to the classical economic theories by Adam Smith and David Ricardo, who argued that international trade is a key factor in economic growth (Abu-Shihab et al. 2014). In 1776, the father of modern economics, Adam Smith, stated in his book The Wealth of Nations (Smith 1776) that in order to achieve the wealth of nations and to make all nations gain from international trade, free and specialized trade must be pursued according to their absolute advantage, otherwise it would be impossible for all nations to become rich at the same time. For example, if both the United States (US) and Japan are producing cars, but Japan can produce cars of a high quality using fewer inputs than the US, which means that Japan has an absolute advantage in the auto industry. It might be better for the US to devote its resources to another industry in which it has an absolute advantage, rather than trying to compete with Japan. David Ricardo (Ricardo 1817) later on reshaped the startlingly simplistic notion to the more dynamic concept of comparative advantage. While absolute advantage refers to the higher production abilities of one nation against other nations, comparative advantage is based on the concept of opportunity cost. Opportunity cost represents the benefits lost when choosing one alternative over another.

The theories of Smith and Ricardo did not specify exactly what factors would give a country a trade advantage. In order to overcome the shortcomings of these theories, economic theories were developed in the 20th century that explain international trade in more details. More specifically, two Swedish economists, Heckscher (1919) and Ohlin (1933), focused their studies on how a country could gain comparative advantage by producing products that utilize their abundant factor of production. The Swedish economists argued that comparative advantage arises from differences in local resources of production in the nation, which is land, labor and capital, rather than differences in productivity (Prakash and Anand 2014). Their theory states that the cost of any factor depends on the supply and demand function. The factor is cheaper if the supply is greater than the demand and it is more expensive if the demand is greater than the supply (Sachithra at al. 2012).

According to Awokuse (2005), trade theory does not provide a definitive guidance on the causal relationship between exports, imports and economic growth and that the debate is usually informed by inferences based on empirical analyses. Details on empirical studies are now presented.

\section{LITERATURE REVIEW}

Economic theory states that trade between countries is not a win-loss situation, but rather each country becomes better off (Mankiw 2016). Trade is of great importance to the economies of countries and is considered as one of the most important means of exploiting the economic resources available, and providing the operational requirements necessary for the production of goods and their disposal to the domestic and foreign markets. In other words, exports and imports play an important role in the development of economies as it allows for an interaction between the 
local economy and other economies in the world and thus providing the necessary resources and skills needed to produce certain goods and services (Vijayasri 2013).

The empirical studies regarding the causal relationship between export, import and economic growth have gained special attention of many researchers over the past decades (see, for example, Awokuse 2007; Ramos 2001 and Çetintaş and Barişik 2009). The attention given to these studies has been partly motivated by the recent developments in time series analyses. It is now recognized that traditional methods applied to study the dynamic path of nonstationary variables may produce spurious outcomes and can be improved (Hassouneh, Serra, and Gil 2010).

Many empirical studies have been made to study the causal relationship between exports, imports and economic growth and show that the dynamic relationship among these three variables gives mixed results. More specifically, results from previous studies can be categorized into three main categories: unidirectional causality, bi-directional causality and no causality between trade (export and import) and economic growth. Unidirectional causality results can be further classified into two groups: export (import)-led growth and growth-led export (import). Differences in results can be explained by the sampling period used, the methodologies applied as well as the different countries studied. Reviews of previous literature and their findings are presented below.

The analysis by Ghartey (1993) studies the causal relationships between exports and economic growth for Taiwan, the US and Japan using Vector Autoregression (VAR) approach. His results suggest that exports growth causes economic growth in Taiwan and economic growth causes exports growth in the US. Results also suggest a feedback causal relationship between exports and economic growth in Japan.

Islam (1998) uses a multivariate Vector Error Correction Model (VECM) to study the causality relationship between exports and economic growth in 15 Asian countries over the period 1967-1991. His results show that a long-run equilibrium relationship exists between exports and GDP in five countries (Bangladesh, India, Nepal, Sri Lanka and Fiji) and that exports cause economic growth in two-thirds of these countries. Awokuse (2007) examines the causality between exports, imports and economic growth in
Bulgaria, Czech Republic and Poland using multivariate cointegration VAR approach. The paper results suggest a bi-directional causal relationship between exports and growth in Bulgaria and a unidirectional causality running from imports to economic growth in the Czech Republic and Poland.

Kim et al. (2007) investigates the relationship between exports, imports, and economic growth in Republic of Korea using quarterly data from 1980 to 2003. In doing so, they apply a VECM. Their results indicate that while imports have a significant positive effect on productivity growth, exports do not. Their results further indicate that imports Granger cause GDP growth due to competitive pressures arising from consumer goods imports and technological transfers from developed countries. Zang and Baimbridge (2012) focus on analyzing the relationship between exports, imports and economic growth for South Korea and Japan by constructing a VAR model. Results indicate that the three variables are cointegrated for both countries, implying that a long-run equilibrium relationship exists. Results also provide evidence of bidirectional causality between imports and economic growth for both countries. Further, Japan seems to experience export-led output growth, while GDP growth in South Korea has a negative effect on export growth.

Hye (2012) examines the relationship between exports, imports and economic growth in the case of China from 1978 to 2009 by using the Autoregressive Distributed Lag (ARDL) technique and modified Granger causality test. Their results support the existence of the bidirectional long run relationship between the economic growth and exports, economic growth and imports, and exports and imports. The study done by Velnampy and Achchuthan (2013) investigates the impact of export and import on the economic growth in Sri Lankan between 1970 and 2010. Their results show a strong positive relationship among export and import and that both export and import have a significant impact on the economic growth. Ronit and Divya (2014) analyze the relationship between exports and GDP growth in the context of India by using annual data for the period between 1969 and 2012. In order to achieve this purpose, a VAR model, Granger causality test as well as an Impulse Response Function (IRF) are used. Their results lead to rejection of the null hypothesis that ELG in favor of the alternative, GLE. The IRF proves that shocks to output growth affect exports, while the converse is not true. 
Using annual data during the period 1990 and 2015, Bakari (2016) investigates the relationship between exports, imports, and economic growth in Canada. Data was tested by using Johansen cointegration analysis of VAR model and the Granger-causality tests. While his results show that there is no cointegration relationship between exports, imports, and output growth, a strong evidence of bidirectional causality from imports to economic growth and from exports to economic growth are found. Akter and Bulbul (2017) investigate the comparative influence of import and export on economic growth of eight developing countries (Bangladesh, Egypt, Indonesia, Iran, Malaysia, Nigeria, Pakistan and Turkey) using annual data from year 2001 to year 2015. In doing so, the techniques of cointegration and VECM are applied. The paper provides evidence for the existence of a cointegration between the variables and that both import and export are important to drive growth of an economy in both short run and long run.

In addition to the above analyses that evaluate the relationship between exports, imports and economic growth across different world markets, a number of studies have been conducted on this topic in Arab and Middle East markets. Some of these studies are reviewed in this study.

The paper by Abou-Stait (2005) is focused to examine the causal flow from exports to economic growth for the Egyptian economy during 1977-2003. Cointegration analysis, VAR and IRF analyses are used in this paper. Results from Johansen cointegration test indicate that exports, imports and GDP are not cointegrated, and that exports Granger cause GDP growth. Results also show that shocks to exports lead to a significant response in GDP. Tsen (2007) examines the relationship of exports, domestic demand and economic growth in the Middle East countries, namely Iran, Bahrain, Oman, Saudi Arabia, Qatar, Syria, and Jordan, by estimating a VECM Granger causality test. The results show that there is a bidirectional Granger causality between exports and economic growth for Bahrain, Oman, Qatar and Jordan.

El Alaoui (2015) analysis the relationship between export, import and economic growth using annual time series data for the Moroccan economy over the period 1980-2013. Cointegration approach as well as Granger causality test based on VECM are applied to achieve the paper objective. Cointegration results confirm the existence of the long-run relationship among the variables studied. The result of Granger causality test shows that there is a long-run causality between exports, imports and economic growth. Test also shows short-run causality between variables. Recently, Saaed and Hussain (2015) investigate the impact of exports and imports on the economic growth of Tunis for the period from 1977 to 2012 using Johansen Cointegration approach as well as Granger causality test in VECM framework. Their results suggest a unidirectional causality between exports and imports and between exports and economic growth. More recently, Kalaitzi and Cleeve (2017) investigate the causality between exports and economic growth in the United Arab Emirates (UAE) over the period 19812012. Johansen cointegration approach as well Granger causality test under VECM are applied to test the existence of a long-run relationship and the direction of the causality between variables, respectively. The cointegration test reveals the existence of a long-run relationship between variables studied. Evidence to support a bi-directional causality between exports and economic growth in the short-run as well as economic growth causes exports in the longrun for UAE are found.

It is worth noting that, in spite of previous attempts to investigate the causal relationship between exports, imports and economic growth, no previous analysis has investigated the Palestinian market, which represents a contribution of this research to the existing literature.

\section{METHODOLOGY}

Many empirical studies have examined the causal link between real GDP, real exports and real imports and found that time series involved are not stationary (Asafu-Adjaye and Chakraborty, 1999; Uğur 2008; Vardari 2015). A series is said to be non-stationary, if the mean, variance and covariance of the level series are not constant over time. Engle and Granger (1987) explain that a long-run equilibrium relationship among non-stationary variables may be exist. The long-run equilibrium relationship between two or more variables, also known in the econometrics literature through the concept of cointegration. According to Engle and Granger (1987), two conditions must be satisfied for variables to be cointegrated. First, the individual series must be integrated of the same order. Second, the linear combinations of the non-stationary variables, derived from an OLS regression, must be stationary. The cointegration relationship among the three series using the Palestinian economic growth as the normalization variable, can be expressed as follows: 


$$
G D P_{t}=\beta_{0}+\beta_{1} E X P_{t}+\beta_{2} I M P_{t}+e_{t}
$$

where $G D P_{t}, E X P_{t}$ and $I M P_{t}$ denote the real GDP, the real exports and the real imports in Palestine at time $t$, respectively and $e_{t}$ is the deviation from the long-run equilibrium relationship, i.e., the Error Correction Term (ECT). According to Engle and Granger (1987), If $G D P_{t}, E X P_{t}$ and $I M P_{t}$ each are non-stationary, but they become stationary after the first differencing, and are found to be cointegrated, then a VECM should be applied to study the short- and long-run causality between variables. ${ }^{1}$ The VECM can be specified as follows:

$$
\begin{aligned}
& \Delta G D P_{t}=\alpha_{1}+\lambda_{G D P} e_{t-1}+\sum_{i=1}^{n} \alpha_{11}(i) \Delta G D P_{t-i}+\sum_{i=1}^{n} \alpha_{12}(i) \Delta E X P_{t-i} \\
& +\sum_{i=1}^{n} \alpha_{13}(i) \Delta I M P_{t-i}+u_{1, t} \\
& \Delta E X P_{t}=\alpha_{2}+\lambda_{E X P} e_{t-1}+\sum_{i=1}^{n} \alpha_{21}(i) \Delta G D P_{t-i}+\sum_{i=1}^{n} \alpha_{22}(i) \Delta E X P_{t-i} \\
& +\sum_{i=1}^{n} \alpha_{23}(i) \Delta I M P_{t-i}+u_{2, t} \\
& \Delta I M P_{t}=\alpha_{3}+\lambda_{I M P} e_{t-1}+\sum_{i=1}^{n} \alpha_{31}(i) \Delta G D P_{t-i}+\sum_{i=1}^{n} \alpha_{23}(i) \Delta E X P_{t-i} \\
& +\sum_{i=1}^{n} \alpha_{33}(i) \Delta I M P_{t-i}+u_{3, t}
\end{aligned}
$$

where $\Delta$ denotes the first difference operator; $\mathrm{n}$ is the number of lags, $u_{1, t}, u_{2, t}$ and $u_{3, t}$ are random error terms; $e_{t-1}\left(G D P_{t-1}-\beta_{0}-\beta_{1} E X P_{t-1}-\beta_{2} I M P_{t-1}\right)$ is the one period lagged of the ECT, which is derived from the long-run cointegration relationship. The $\alpha$ terms are all short-run dynamics parameters and $\lambda_{G D P}, \lambda_{E X P}$ and $\lambda_{I M P}$ are known as the speed of adjustment parameters and represent the deviation of dependent variables from the long-run equilibrium relationship.

In each equation, the change in the dependent
variable depends not only on $\Delta G D P_{t-i}, \Delta E X P_{t-i}$ and $\Delta I M P_{t-i}$, but also on the one period lagged of the equilibrium error term, $e_{t-1}$. Given such a specification, the VECM is applied for investigating short- and long-run causality. Let us consider the GDP equation. If the estimated coefficients on lagged values of exports $\left(\alpha_{12} s\right)$ are statistically different from zero, then the implication is that real exports Granger-causes

\footnotetext{
${ }^{1}$ In line with the economic theory and other empirical analyses that have found evidence of symmetric adjustment among time series variables within different markets (Hassouneh et al. 2015; Ferrucci et al. 2012), the VECM is adopted in this paper.
}

real GDP in the short run. By testing the significance of the lagged values of imports coefficients $\left(\alpha_{13} s\right)$, the short run causality running from real imports to real GDP can be checked. The long-run causality can be tested be examining the significance of the error correction parameter $\left(\lambda_{G D P}\right)$.

Our particular estimation methodology can be outlined as follow. First, standard unit root and cointegration tests are applied in order to decide whether real GDP, real exports and real imports series are stationary and whether they are cointegrated, respectively. Specifically, standard augmented Dickey and Fuller (1979), Phillips and Perron (1988) and Kwiatkowski-Phillips-Schmidt-Shin (KPSS, Kwiatkowski et al. 1992) tests for each series are applied. The Johannsen's maximum likelihood (Johansen 1988) cointegration test procedure is then used to investigate the presence of long-run relationship among series studied. ${ }^{2}$ Second, a linear VECM is utilized to fit the data analyzed.

\section{VARIABLES DEFINITIONS AND DATA SOURCES}

Our empirical model utilizes three series of real GDP (base year 2010), exports and imports. The data set is quarterly and covers the period from the first quarter of 2000 to the first quarter of 2018, yielding a total of 73 observations. Data used for all variables are obtained from the PCBS (2018) and are expressed in million Dollars. Both exports and imports are deflated by consumer price index, using 2010 as the base year. Figure 1, shows the time series of real GDP growth (GDP), real exports (exports) and real imports (imports) in Palestine during the study period. The mean of GDP, exports and imports are 1,883.2, 155.3, and 961.1 million dollars, respectively, and the standard deviation are, respectively, 520.8035, 50.7263 and 226.0951 million dollars.

\section{EMPIRICAL ANALYSIS}

Our empirical analysis is based on a logarithmic transformations of time series data. A log transformation is applied to reduce heteroscedasticity. As we mentioned earlier, standard augmented DickeyFuller (1979), Phillips and Perron (1988) and KPSS (Kwiatkowski et al. 1992) tests are applied to each

\footnotetext{
${ }^{2}$ Several methods have been developed to test for long-run linkages among series. In this paper and in line with the recommendation by Enders (1995) when studying three or more variables, Johansen (1988) cointegration test is applied.
} 


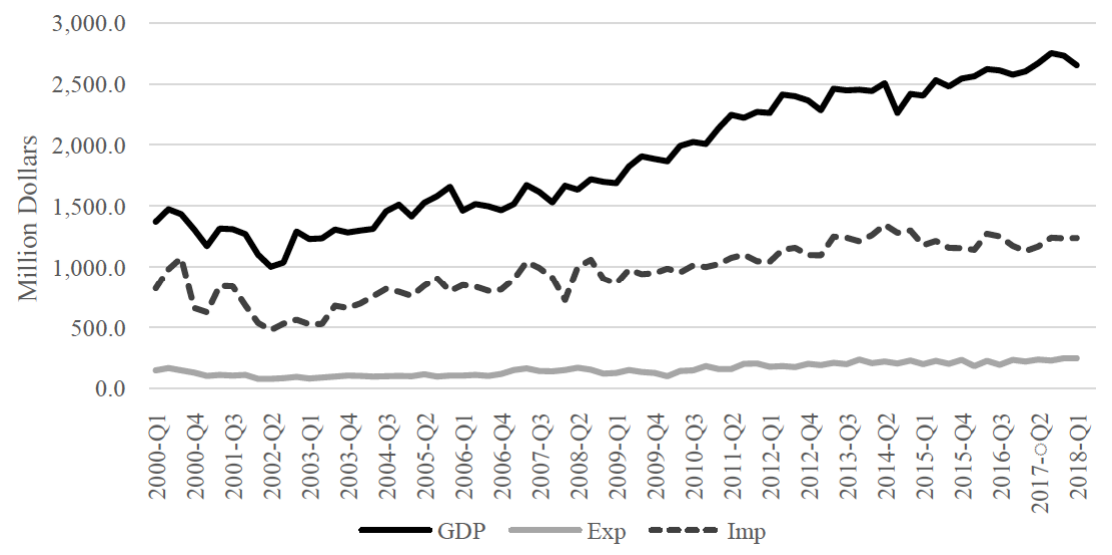

Figure 1: Quarterly Palestinian real GDP, real exports and real imports.

Table 1: Unit Root Tests

\begin{tabular}{|c|c|c|c|c|c|c|}
\hline \multirow{2}{*}{ Variables } & \multicolumn{2}{|c|}{ ADF test statistics } & \multicolumn{2}{c|}{ PP test statistics } & \multicolumn{2}{c|}{ KPSS test statistics } \\
\cline { 2 - 7 } & Level & First difference & Level & First difference & Level & First difference \\
\hline \hline GDP & -0.139 & -7.664 & -0.213 & -9.839 & 1.089 & 0.090 \\
\hline EXP & 0.026 & -8.158 & -1.112 & -12.099 & 0.962 & 0.265 \\
\hline IMP & -0.735 & -10.436 & -1.688 & -12.771 & 0.930 & 0.206 \\
\hline $5 \%$ critical value & -2.903 & -2.903 & -2.903 & -2.903 & 0.463 & 0.463 \\
\hline $10 \%$ critical value & -2.589 & -2.589 & -2.589 & -2.589 & 0.347 & 0.347 \\
\hline
\end{tabular}

Note: Critical values for the ADF, PP tests are obtained from Mackinnon (1991) and the KPSS test from Kwiatkowski et al. (1992). Each test uses an intercept and no trend.

series in order to determine whether time series data contain unit root or not. As shown in Table 1, results assure that the GDP, export and import are nonstationary at level. However, non-stationarity can be rejected when applied to first-differenced time series at the $5 \%$ significance level. In other words, variables are integrated of the same order I(1).

Once confirmed that GDP, export and import series are integrated of order one I(1), Johansen's (1988) cointegration test is applied to detect any possible longrun equilibrium relationship between the I(1) variables. Results of Johansen cointegration, as shown in Table 2 , suggest the existence of a single cointegration relationship between economic growth, export and import series. ${ }^{3}$ Other analyses have also found evidence of cointegration between economic growth, export and import (see, El Alaoui 2015; Ucan, Akyildiz, and Maimaitimansuer 2016; Guntukula 2018).

The cointegration equation indicates that both exports and imports positively influence economic

${ }^{3}$ It is worth noting that Engle and Granger (1987) cointegration technique is also performed and suggests that the hypothesis of no cointegration can be rejected at the $5 \%$ significance level. growth at the long run. More specifically, the test results suggest that a $10 \%$ increase (decrease) in exports lead to a $5.7 \%$ increase (decrease) in output growth. Results also show that a $10 \%$ increase (decrease) in imports will be followed by a $3.9 \%$ increase (decrease) in GDP. While, the positive relationship between exports and economic growth is consistent with the economic theory, the positive effect of import on GDP growth is not. These results are not surprising and are consistent with the Palestinian context. Specifically, imports are likely to promote economic growth due to the fact that intermediate goods and capital goods (i.e., new technology) constitute an important proportion of Palestinian imports (World Bank 2017). Obviously, the increase in foreign intermediate and capital goods can accelerate production and enhance the domestic investment which is positively associated with economic growth. These findings are in line with previous literature that has shown that imports led output growth (see, for example, Iscan 1998; Damooei and Tavakoli 2006; Maina 2008).

After confirming the presence of cointegration, the VECM is applied to investigate both the short- and 
Table 2: Johansen Cointegration Test and Cointegration Equation

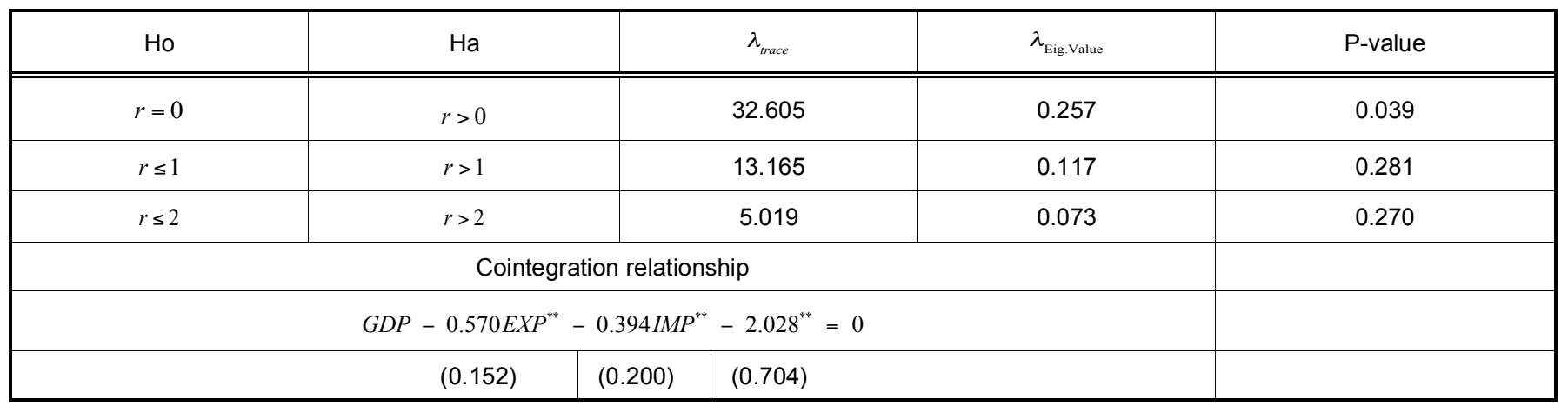

Notes: $r$ is the cointegration rank. ${ }^{* *}$ denotes statistical significance at the $5 \%$ level. Standard errors in parenthesis.

long-run causality of the series. Results of the VECM are presented in Table 3. Each column represents an equation for each of the three variables in the system. As stated above, $e_{t-1}$ coefficients (a one period lag of the cointegration equation) indicate whether there is a long-run causal relationship between variables or not. To examine the short-run causality, the lagged first differences of all the endogenous variables in the system are used. The lag lengths to be used in the VECM model, are chosen by using Akaike's Information Criterion (AIC). In our analysis, AIC criteria recommends using only one lag.

We first focus on the long-run causality. It can be seen that the coefficients of the error correction term $\left(e_{t-1}\right)$ in the GDP, export and import equations are statistically significant and have the right signs. Hence, results suggest a long-run feedback causal relationship between exports, imports and output growth in Palestine. More specifically, results indicate that the hypotheses, export (import)-led growth and growth-led export (import), are supported at the 10\% significance level. Other studies have also found a bidirectional long-run causality among export, import and economic growth (Sharma and Smyth 2009). The statistically significant error correction term also shows evidence in support of long-run causal relationship from exports to imports and the reverse long-run causation from imports to exports is also supported. These results indicate that both exports and imports are viewed as key determinants of economic growth in Palestine.

We now focus on discussing the short-run model findings. Results suggest that imports Granger causes GDP at the $5 \%$ significance level $(0.243)$, but the reverse short-run causation from output growth to imports is not supported. The empirical results also indicate that both the export-led import and the importled export hypotheses are statistically significant at the $10 \%$ level. Results can be explained as a part of capital goods and raw materials that are imported for merchandise exports. In other words, increasing the import of raw materials is considered as a source of production of exported goods.

To better understand the dynamic relationship between exports, imports and economic growth, an Impulse Response Function (IRF) is applied. IRF provides an effective way to predict the time path of the response of a variable to shocks to the system (Lütkepohl, 2005).

Figures 2 and 3 show the responses of economic growth to one positive standard deviation shock to the import and export, respectively. Figure 2 shows that an increase in import causes an increase in the economic growth. The economic growth increases during the first

Table 3: Granger Causality Test Results Based on VECM

\begin{tabular}{|c|c|c|c|}
\hline Dependent variable & GDP equation & Export equation & Import equation \\
\hline \hline$e_{\mathrm{t}-1}$ & $-0.109^{*}(0.068)$ & $0.637^{* *}(0.141)$ & $0.388^{* *}(0.140)$ \\
\hline$\Delta \mathrm{GDP}_{\mathrm{t}-1}$ & - & $0.070(0.247)$ & $-0.266(0.283)$ \\
\hline$\Delta \mathrm{EXP}_{\mathrm{t}-1}$ & $0.021(0.056)$ & - & $0.220^{*}(0.115)$ \\
\hline$\Delta \mathrm{MPP}_{\mathrm{t}-1}$ & $0.243^{* *}(0.065)$ & $0.376^{* *}(0.135)$ & - \\
\hline
\end{tabular}

Notes: Number in parentheses are standard errors.

**and *denote statistical significance at the $5 \%$ and $10 \%$ significance levels, respectively. 


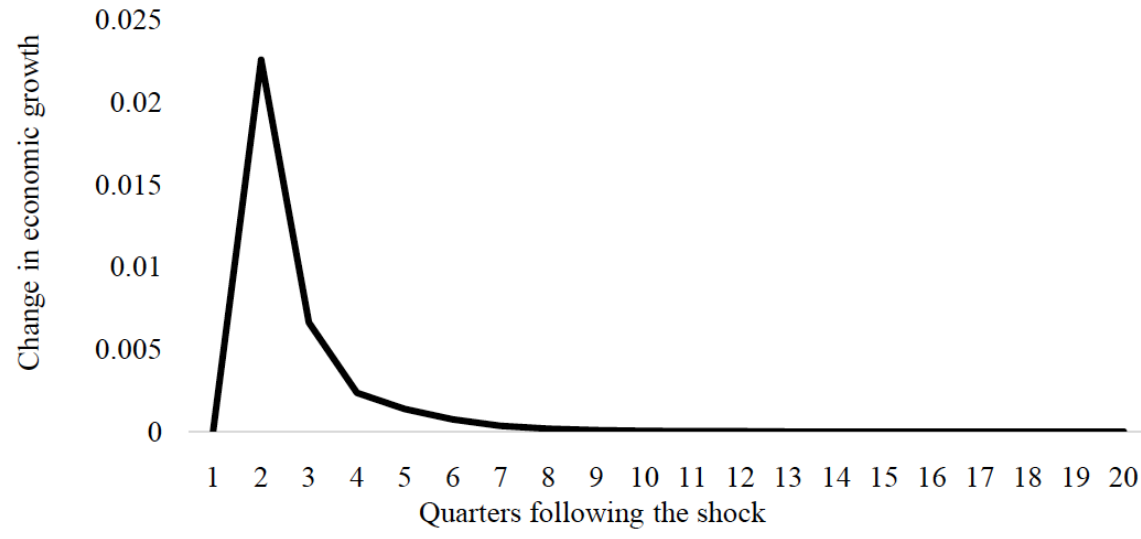

Figure 2: Economic growth response to one positive standard deviation shock to the import.

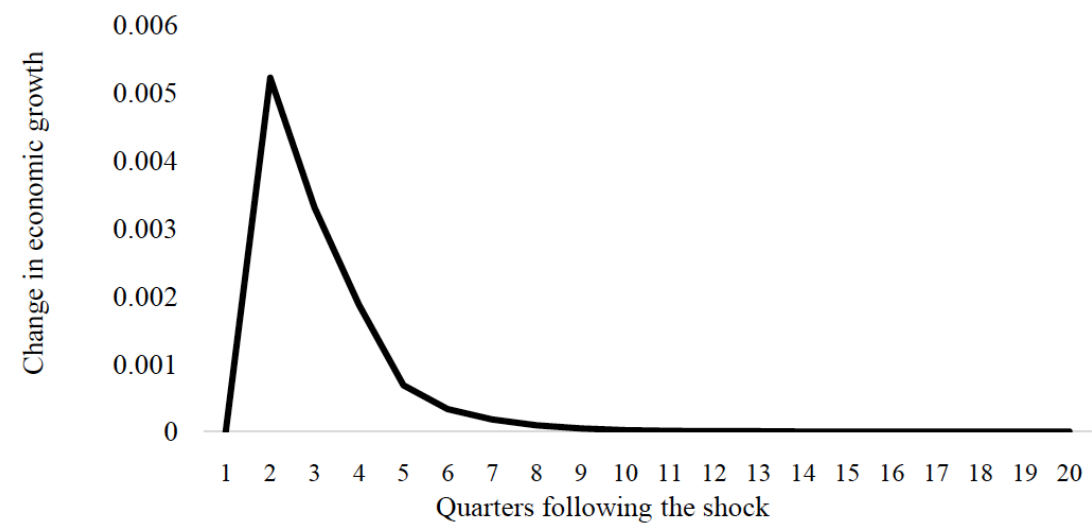

Figure 3: Economic growth response to one positive standard deviation shock to the export.

2 quarters following the shock and decreases thereafter, disappearing after about 8 quarters. A positive one standard deviation shock to the export in Palestine is also seen to cause an increase in the economic growth. This increase gains strength during the first 2 quarters after the shock and shrinks thereafter, disappearing after about 9 quarters (see Figure 3).

Figures 4 and 5 illustrate the responses of export to one positive standard deviation shock to the import and economic growth, respectively. An increase in import is seen to cause an increase in the export, especially during the first two quarters. The effect of import shock disappears after about 9 quarters (see Figure 4). The response of export to an increase in economic growth is also seen to be positive and to disappear after about 9 quarters (see Figure 5).

Figures 6 and 7 depict the responses of import to one positive standard deviation shock to the export and

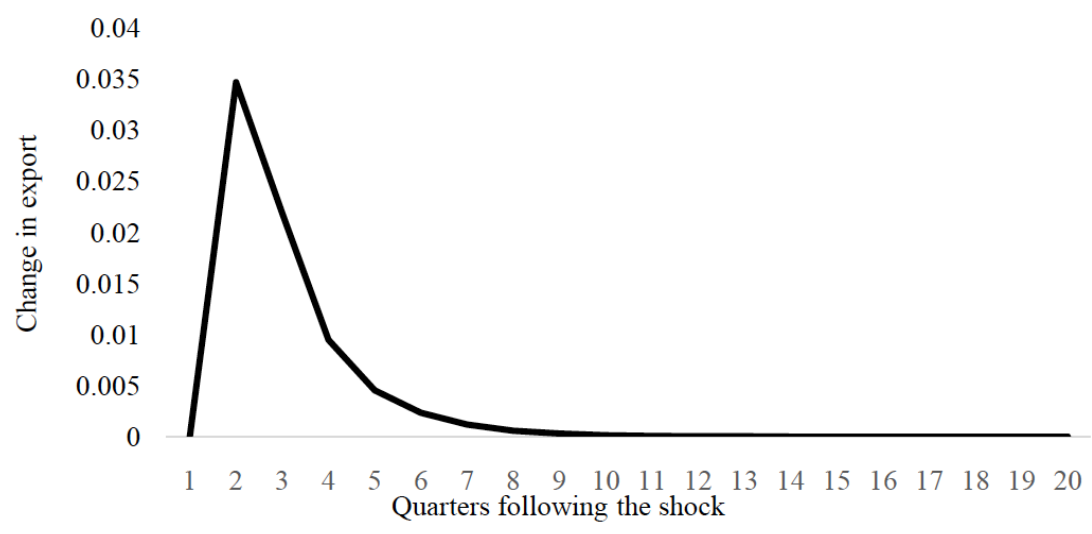

Figure 4: Export response to one positive standard deviation shock to the import. 


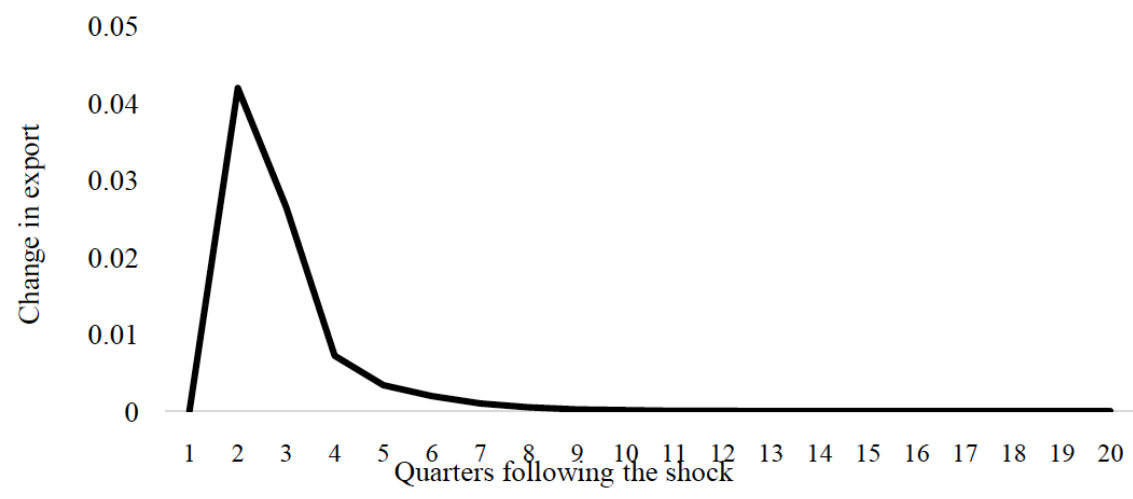

Figure 5: Export response to one positive standard deviation shock to the economic growth.

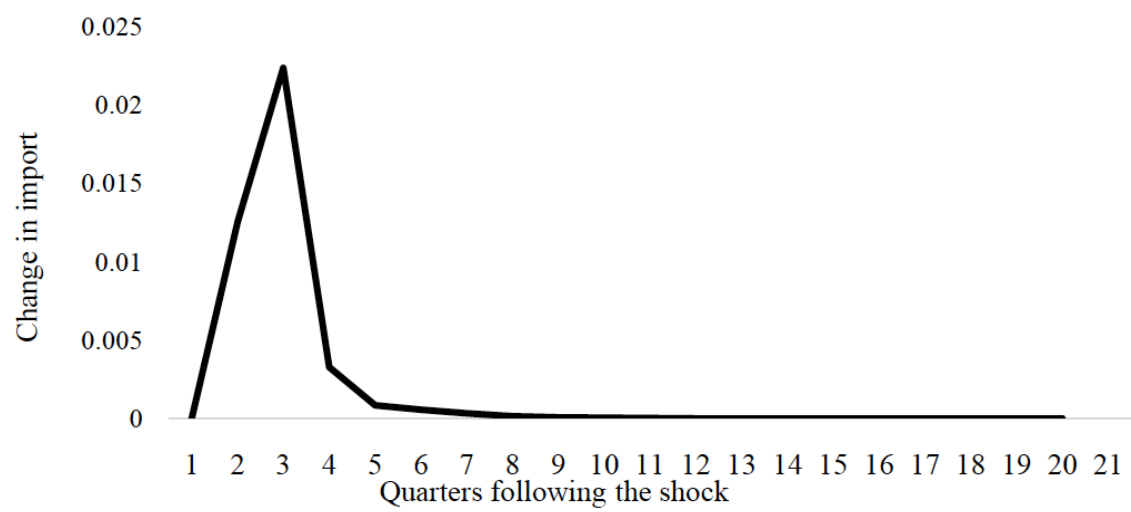

Figure 6: Import response to one positive standard deviation shock to the export.

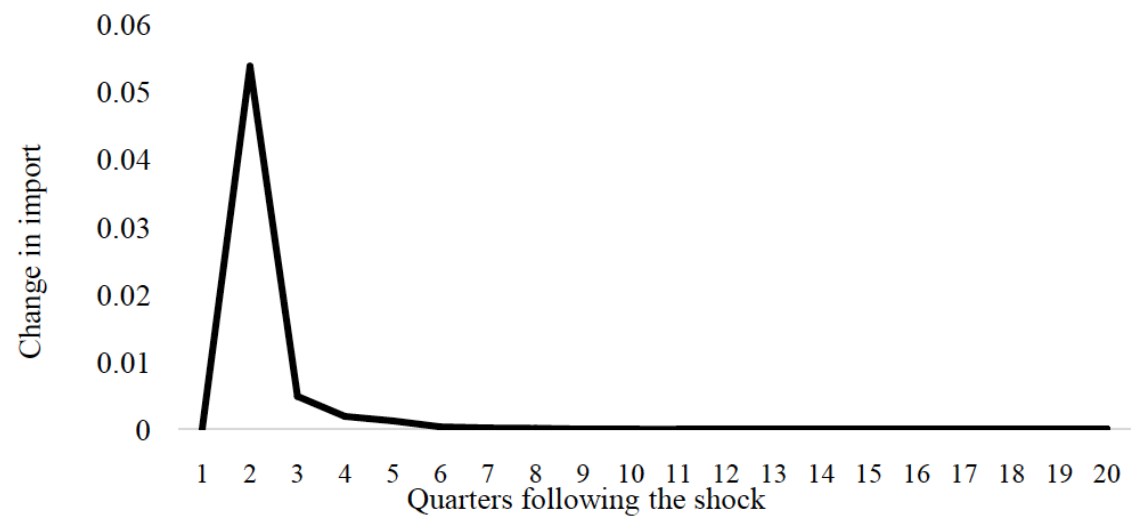

Figure 7: Import response to one positive standard deviation shock to the economic growth.

economic growth, respectively. Figure 6 shows that import exhibits a sharp increase during the first 3 quarters following the shock disappearing after about 7 quarters. Shocks to the economic growth also cause an increase in the import. The import increases during the first 2 quarters and it requires about 6 quarters to complete (see Figure 7).

\section{CONCLUDING REMARKS}

Over the last decades, there has been much interest devoted to the role of foreign trade as an engine of economic growth. However, the Palestinian economy has not received any attention within these empirical analyses. This study contributes to the literature by studying the causal relationship between exports, imports and economic growth in Palestine, a country that has a unique political, socio-economic and developmental situation.

To achieve the study objective. First, standard unit root tests are applied in order to determine whether time series are stationary or not. Second, cointegration and error correction technique are conducted to test for 
both long and short-run causality between exports, imports and real economic growth. Standard unit root test results suggest that all data series are integrated of order one. Cointegration tests provide evidence of a long-run equilibrium relationship between exports, imports and economic growth series. The estimated error correction approach suggests a long-run bidirectional causality among exports, imports and economic growth in Palestine. On the other hand, short run results provide evidence to support export-led import and import-led export hypotheses. Impulse response functions suggest that a positive shock to one variable in the system generates responses in the other variables in same direction.

Although there are many factors that contribute to output growth, increasing economic growth in Palestine requires increasing both exports and imports. More specifically, results suggest a strong relationship among exports and economic growth and thus policy makers should motivate Palestinian companies to enter the international markets for economic growth. On the other hand, imports play an important role in stimulating economic growth.

To sum, a policy for increasing exports and imports, is likely to stimulate economic growth for Palestine. Efforts must be made to encourage Palestinian government to develop strategies that can promote trade.

\section{REFERENCES}

Abou-Stait, Fouad. 2005. "Are exports the engine of economic growth? An application of cointegration and causality analysis for Egypt." Economic Research Working Paper series 76 .

Abu-Shihab, Ruba, Thikraiat Soufan and Shatha Abdul-Khaliq. 2014. "The causal relationship between exports and economic growth in Jordan." International Journal of Business and Social Science 5(3): 302-308.

Asafu-Adjaye, John and Debasish Chakraborty. 1999. "Export-led growth and import compression: further time series evidence from LDCS." Australian Economic Papers 38(2): 164-175. https://doi.org/10.1111/1467-8454.00049

kter, Maimuna and Md Nahid Bulbul. 2017. "Comparative analysis between export-led growth and import-led growth: a study on developing eight (d-8)." Science Puplishing Group 5(4): 204212.

Awokuse, Titus O. 2005. "Exports, economic growth and causality in Korea." Applied Economics Letters 12(11): 693-696. https://doi.org/10.1080/13504850500188265

Awokuse, Titus O. 2007. "Causality between exports, imports, and economic growth: evidence from transition economies." Economics Letters 94(3): 389-395. https://doi.org/10.1016/j.econlet.2006.08.025

Bakari, Sayef and Mohamed Mabrouki. 2017. "Impact of exports and imports on economic growth: new evidence from Panama." Journal of Smart Economic Growth 2(1): 67-79.
Bakari, Sayef. 2016. "Impact of exports and imports on economic growth in Canada: empirical analysis based on causality." MPRA Paper75910.

Çetintaş, Hakan and Salih Barişik. 2009. "Export, import and economic growth: the case of transition economies." Transition Studies Review 15(4): 636-649. https://doi.org/10.1007/s11300-008-0043-0

Chokri, Terzi, Anis El Ammari and Ali Bouchrika. 2018. "Optimal Taxation and Economic Growth in Tunisia: Short and Long Run Analysis." Journal of Reviews on Global Economics 7: 157-164. https://doi.org/10.6000/1929-7092.2018.07.14

Damooei, Jamshid and Akbar Tavakoli, A. 2006. "The effects of foreign direct investment and imports on economic growth: a comparative analysis of Thailand and the Philippines (19701998)". The Journal of Developing Areas 39(2): 79-100. https://doi.org/10.1353/jda.2006.0002

Dickey, David. and Wayne A. Fuller. 1979. "Distribution of the Estimators for Autoregressive Time Series With a Unit Root." Journal of the American Statistical Association 74(366): 427431.

https://doi.org/10.2307/2286348

El Alaoui, Aicha. 2015. "Causality and cointegration between export, import and economic growth: evidence from Morocco." Journal of World Economic Research 4(3): 83-91. https://doi.org/10.11648/j.jwer.20150403.14

Enders, Walter. 1995. Applied Econometric Time Series. lowa: lowa State University.

Engle, Robert F. and C. W. J. Granger. 1987. "Cointegration and error correction: representation, estimation and testing." Econometrica 55(2): 251-276. https://doi.org/10.2307/1913236

Ferrucci, Gianluigi, Rebeca Jiménez-Rodríguez and Luca Onorantea. 2012. "Food Price Pass-Through in the Euro Area: NonLinearities and the Role of the Common Agricultural Policy." International Journal of Central Banking, 8(1): 179-217.

Ghartey, Edward. 1993. "Causal relationship between exports and economic growth: some empirical evidence in Taiwan, Japan and the US." Applied economics 25(9): $1145-1152$. https://doi.org/10.1080/00036849300000175

Guntukula, Raju. 2018. "Exports, imports and economic growth in India: evidence from cointegration and causality analysis." University of Hyderabad, India 2(615): 221-230.

Hashem, Khairul and Mansur Masih. 2014. "What causes economic growth in Malaysia: exports or imports?" MPRA Paper 62366.

Hassouneh, Islam, Teresa Serra and José M. Gil. 2010. "Price transmission in the Spanish bovine sector: the BSE effect." Agricultural Economics 41(1): 33-42. https://doi.org/10.1111/j.1574-0862.2009.00423.x

Hassouneh, Islam, Carsten Holst, Teresa Serra, Stephan von Cramon-Taubadel and José M. Gil, 2015. "Overview of Price Transmission and Reasons for Different Adjustment Patterns across EU Member States". Chapter 3 in S. McCorriston (ed). Food Price Dynamics and Price Adjustment in the EU. Oxford University Press, Oxford. https://doi.org/10.1093/acprof:oso/9780198732396.003.0003

Heckscher, Eli. 1919. "The effects of foreign trade on the distribution of income." Ekonomisk Tidskrift 21: 497-12.

Helpman, Elhanan and Paul R. Krugman. 1985. Market Structure and Foreign Trade: Increasing Returns, Imperfect Competition and The International Economy. MIT Press: Cambridge, MA.

Hye, Qazi Muhammad Adnan. 2012. "Exports, imports and economic growth in China: an ARDL analysis." Journal of Chinese Economic and Foreign Trade Studies 5(1): 42-55. https://doi.org/10.1108/17544401211197959 
Hye, Qazi Muhammad Adnan, Shahida Wizarat and Wee-YeapLau. 2013. "Trade-led growth hypothesis: an empirical analysis of South Asian countries." Economic Modelling 35: 654-660. https://doi.org/10.1016/j.econmod.2013.07.040

Iscan, Talan. 1998. "Trade liberalization and productivity: a panel study of the Mexican manufacturing industry." The Journal of Development Studies 34(5): 123-148. https://doi.org/10.1080/00220389808422539

Islam, Muhammed N. 1998. "Export expansion and economic growth: testing for cointegration and causality." Applied Economics 30: $43-423$. https://doi.org/10.1080/000368498325930

Johansen, Søren. 1988. "Statistical analysis of cointegration vectors." Johansen of Economics Dynamics and Control 12: 231-254. https://doi.org/10.1016/0165-1889(88)90041-3

Kalaitzi, Athanasia S and Emmanuel Cleeve. 2017. "Export-led growth in the UAE: multivariate causality between primary exports, manufactured exports and economic growth." Eurasian Business Review 8(3): 341-365. https://doi.org/10.1007/s40821-017-0089-1

Kim, Sangho, Hyunjoon Lim and Donghyun Park. 2007. "Could imports be beneficial for economic growth: some evidence from republic of Korea." ERD working paper series 103.

Krugman Paul R. 1984. Import Protection as Export Promotion. In: Kierzkowski, H. (Ed.), Monopolistic Competition in International Trade. Oxford: Oxford University Press.

Kubo, Akihiro. 2011. "Trade and economic growth: Is export-led growth passé?" Economics Bulletin 31(2): 1623-1630.

Kwiatkowski, Denis, Peter C.B. Phillips, Peter Schmidt and Yongcheol Shin. 1992. "Testing the Null Hypothesis of Stationarity against the Alternative of a Unit Root." Journal of Econometrics 54: 159-178. https://doi.org/10.1016/0304-4076(92)90104-Y

Lawrence, Robert Z. and David E. Weinstein. 1999. "Trade and growth: import-led or export-led? evidence from Japan and Korea." NBER Working Papers 7264.

Lütkepohl, Helmut. 2005. New introduction to multiple time series analysis. Springer-Verlag, Berlin. https://doi.org/10.1007/978-3-540-27752-1

Maina, Rufus Marundu. 2008. "The effect of exports and imports on economic growth: empirical evidence from Kenya." The university of Nairobi (UoN) D61(71539).

MacKinnon, James G. 1991. Critical values for cointegration tests. in R.F. Engle and C. W. J. Granger (eds), Long Run Economic Relationships, Oxford University Press, 267-276.

Mankiw, N. Gregory. 2016. Principles Of Microeconomics. USA: Cengage Learning.

Ohlin, Bertil. 1933. Interregional and International Trade. Cambridge: Harvard University Press.

PCBS. 2018. Dataset. http://www.pcbs.gov.ps/. Accessed October 2018.

Phillips, Peter C. B. and Pierre Perron. 1988. "Testing for a unit root in time series regression." Biometrika 75(2): 335-346. https://doi.org/10.1093/biomet/75.2.335

Prakash, Shri and Sonia Anand. 2014. "Impact of growth on factor endowment and structure of India's trade." IOSR Journal of Economics and Finance 5(5): 53-66. https://doi.org/10.9790/5933-0555366
Ramos, Francisco F. Ribeiro. 2001. "Exports, imports, and economic growth in Portugal: evidence from causality and cointegration analysis." Economic Modelling 18(4): 613-623. https://doi.org/10.1016/S0264-9993(00)00055-9

Ricardo, David. 1817. On the Principles of Political Economy and Taxation. London: John Murray.

Ronit, Mukherji and Pandey Divya. 2014. "The relationship between the growth of exports and growth of gross domestic product of India." International Journal of Business and Economics Research 3 (3): 135-139.

https://doi.org/10.11648/j.ijber.20140303.13

Saaed, Afaf Abdull J and Majeed Ali Hussain. 2015. "Impact of exports and imports on economic growth: evidence from Tunisia." Journal of Emerging Trends in Economics and Management Sciences (JETEMS) 6(1): 3-21.

Sachithra, K. M. V., G. A. C Sajeevi, M. P. K. Withanawasm and W. M. S. A. Jayathilake. 2012. "Comparative advantage in international trade: a study based on leading exports in Sri Lanka." Kelaniya Journal of Management 1(2): 51-85. https://doi.org/10.4038/kjm.v1i2.6453

Sharma, Susan Sunila and Russell Smyth. 2009. "Is economic growth export-led or import-led in the pacific island countries? Evidence from panel data models." Monash University Development Research Unit Discussion Paper 915.

Smith, Adam. 1776. An Inquiry into the Nature and Causes of the Wealth of Nations. Edited by S. M. Soares. MetaLibri Digital Library, 2007.

Ucan, Okyay, Abdulmenaf Akyildiz and Maimaitiaili Maimaitimansuer. 2016. "The relationship between export and economic growth in Turkey." European Scientific Journal (1):61-70.

Uğur, Ahmet. 2008. "Import and Economic Growth in Turkey: Evidence from Multivariate VAR Analysis." East-West Journal of Economics and Business 11(1-2): 54-75.

Vardari, Msc. Luan. 2015. "Relationship between import-exports and economic growth: the Kosova case study." Revista Shkencore Regjionale (REFORMA) 3: 262-269. https://doi.org/10.2139/ssrn.2889731

Velnampy, T and Achchuthan, S. 2013. "Export, import and economic growth: evidence from Sri Lanka." Journal of Economic and Sustainable Development 4(9): 147-155.

Vijayasri, G. V. 2013. "The importance of international trade in the world." International Journal of Marketing, Financial Services \& Management Research 2(9): 111-119.

Tsen, Wong Hock. 2007. "Export, domestic demand and economic growth: some empirical evidence of the Middle East countries." Journal of Economic Cooperation 28(2): 57-82.

World Bank. 2017. Unlocking the trade potential of the Palestinian economy: immediate measures and a long-term vision to improve Palestinian trade and economic outcomes (English). Washington, D.C.: World Bank Group. http://documents.worldbank.org/curated/en/96007151322885 6631/Unlocking-the-trade-potential-of-the-Palestinianeconomy-immediate-measures-and-a-long-term-vision-toimprove-Palestinian-trade-and-economic-outcomes. Accessed January 2019.

Zang, Wenyu and Mark Baimbridge. 2012. "Exports, imports and economic growth in South Korea and Japan: a tale of two economies." Applied Economics 44(3): 361-372. https://doi.org/10.1080/00036846.2010.508722

\section{DOI: https://doi.org/10.6000/1929-7092.2019.08.22}

(C) 2019 Fannoun and Hassouneh; Licensee Lifescience Global.

This is an open access article licensed under the terms of the Creative Commons Attribution Non-Commercial License (http://creativecommons.org/licenses/by-nc/3.0/) which permits unrestricted, non-commercial use, distribution and reproduction in any medium, provided the work is properly cited. 